\title{
Expression and regulation of the ery operon of Brucella melitensis in human trophoblast cells
}

\author{
HUI ZHANG ${ }^{1-3^{*}}$, XIAOXIA DOU ${ }^{1 *}$, ZHIQIANG LI $^{4}$, YU ZHANG ${ }^{1}$, JING ZHANG ${ }^{1}$, FEI GUO ${ }^{3,5}$,

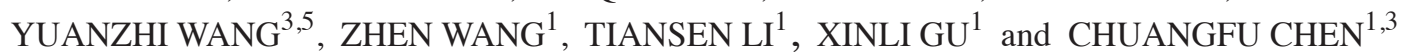

\author{
${ }^{1}$ College of Animal Science and Technology; ${ }^{2}$ State Key Laboratory for Sheep Genetic Improvement and Healthy Production; \\ ${ }^{3}$ Co-Innovation Center for Zoonotic Infectious Diseases in The Western Region, Shihezi University, Shihezi, Xinjiang 832000; \\ ${ }^{4}$ School of Life Sciences, Shangqiu Normal University, Shangqiu, Henan 476000; \\ ${ }^{5}$ School of Medicine, Shihezi University, Shihezi, Xinjiang 832000, P.R. China
}

Received April 28, 2015; Accepted May 18, 2016

DOI: $10.3892 / \mathrm{etm} .2016 .3688$

\begin{abstract}
Brucellosis is primarily a disease of domestic animals in which the bacteria localizes to fetal tissues such as embryonic trophoblast cells and fluids containing erythritol, which stimulates Brucella spp. growth. The utilization of erythritol is a characteristic of the genus Brucella. The ery operon contains four genes (eryA, eryB, eryC and eryD) for the utilization of erythritol, and plays a major role in the survival and multiplication of Brucella spp. The objective of the present study was to conduct a preliminary characterization of differential genes expression of the ery operon at several time points after Brucella infected embryonic trophoblast cells (HPT-8 cells). The result showed that the ery operon expression was higher in HPT-8 cells compared with the medium. The relative expression of ery $A, \operatorname{ery} B$ and $\operatorname{ery} C$ peaked at $2 \mathrm{~h}$ post-infection in HPT- 8 cells, and eryD expression peaked at $3 \mathrm{~h}$ post-infection. The expression of eryA, eryB and eryC may be inhibited by increased $\operatorname{ery} D$ expression. However, the expression of the ery operon was stable in the presence

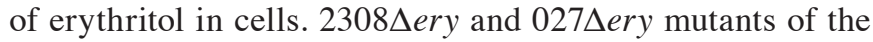
ery operon were successfully constructed by homologous recombination, which were attenuated in RAW 264.7 murine macrophages. The characterization of the ery operon genes and their expression profiles in response to Brucella infection further contributes to our understanding of the molecular mechanisms of infection and the pathogenesis of brucellosis.
\end{abstract}

Correspondence to: Xinli $\mathrm{Gu}$ and Chuangfu Chen, College of Animal Science and Technology, Shihezi University, 221 North 4th Road, Shihezi, Xinjiang 832000, P.R. China E-mail: guxinlidky@sohu.com; chuangfu_chen@163.com

*Contributed equally

Key words: Brucella melitensis, ery operon, reverse transcription-quantitative polymerase chain reaction, HPT-8 cells

\section{Introduction}

The Gram-negative bacteria Brucella causes Brucellosis, a zoonotic disease that is widely disseminated throughout the world (1). In humans, Brucellosis causes undulant fever, arthritis and myocarditis (2). Brucella spp. are able to survive and multiply inside the placenta and fetus of pregnant mammals, causing abortion during pregnancy (3). The interactions between Brucella and their hosts are extremely complex, as these facultative intracellular parasites are able to adapt to the harsh environment of host cells, which include oxidative damage, nitrosative damage, acidic $\mathrm{pH}$, antimicrobial peptides and nutrient deprivation (4,5). Brucella spp. are able to achieve this by regulating gene expression differently when growing in vitro or in vivo. However, the mechanisms underlying this survival and multiplication within host cells require further characterization.

Brucella spp. have a tropism for cells containing erythritol, such as embryo-trophoblasts found in the placenta (6), and erythritol has a growth-promoting effect on some Brucella strains. Therefore, Brucella spp. are able to colonize and reproduce in embryo trophoblast cells, which can cause placentitis and result in abortion (7). Furthermore, the virulence of Brucella spp. is correlated with erythritol metabolism (8), and the Brucella-encoded catabolic erythritol pathways are required for intracellular survival (9). Erythritol usage relies on the ery operon, which consists of the genes eryA, eryB, eryC and eryD (10). The eryA gene encodes a 519 amino acids (AA) putative erythritol kinase (10). The ery $B$ gene encodes an erythritol phosphate dehydrogenase (10). The eryC gene product has been assigned as a D-erythrulose-1-phosphate dehydrogenase, and the eryD gene encodes a regulator of ery operon expression (10-12). Although ery operon expression is correlated with erythritol metabolism, growth conditions can regulate gene expression (10). To understand ery operon regulation in Brucella melitensis during infection, we examined gene expression at several timepoints following growth in HPT-8 trophoblast cells. The results help to characterize the mechanisms required for Brucella spp. pathogenesis. 


\section{Materials and methods}

Bacterial strains, plasmids and growth conditions. Table I lists the strains and constructed plasmids used in this study. Brucella abortus 2308 was obtained from the Chinese Center of Disease Prevention and Control (CDC; Beijing, China). B. melitensis 027 strain was isolated from Xinjiang, China, and was identified by the CDC. Brucella strains were cultured in tryptic soy agar (TSA) or tryptic soy broth (TSB; Sigma-Aldrich, St. Louis, MO, USA). Plates were incubated at a temperature of $37^{\circ} \mathrm{C}$ in an atmosphere enriched with $5 \%$ $\mathrm{CO}_{2}$. Escherichia coli strain JM109 (Promega Corporation, Madison, WI, USA) was grown in Luria-Bertani (LB) media. The culture media were supplemented with $50 \mu \mathrm{g} / \mathrm{ml}$ ampicillin (Invitrogen; Thermo Fisher Scientific, Inc., Carlsbad, CA, USA). The plasmid pMD18-T Simple Vector was purchased from Takara Bio, Inc. (Otsu, Japan). The standard curves were constructed using pMD18-T Simple Vector.

Cells. Murine macrophages (RAW 264.7) and human trophoblasts (HPT-8) were used in this study. HPT- 8 cells and RAW 264.7 murine macrophage were purchased from the Cell Resource Center, IBMS, CAMS/PUMC (Beijing, China).

Construction of 23084ery and 0274ery. Deletion of the ery operon in B. abortus 2308 and B. melitensis 027 (2308_ery and $027 \Delta e r y$ ) was performed as previously described (13).

Growth curve of 23084ery and 0274ery. To monitor the

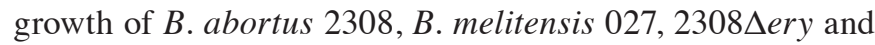
$027 \Delta$ ery, cells were cultured in TSB to an optical density at $600 \mathrm{~nm}$ (OD600) of 0.6, then diluted with TSB to an OD600 of 0.05 and cultured in rotary shaker $(100.62 \mathrm{x} \mathrm{g})$ at $37^{\circ} \mathrm{C}$ for $48 \mathrm{~h}$. Aliquots of cultures were collected at 4-h intervals, and bacterial growth was measured at OD600.

Erythritol sensitivity of 23084ery and 027Aery. To detect erythritol sensitivity in $2308 \Delta e r y$ and $027 \Delta$ ery, stationary phase pre-cultures of $B$. abortus $2308, B$. melitensis 027 , $2308 \Delta$ ery and $027 \Delta$ ery were diluted in TSB containing $20 \mathrm{mM}$ erythritol (Sigma-Aldrich), and grown for $48 \mathrm{~h}$. The bacterial growth was measured at an OD600.

Evaluation of 23084ery and 0274ery attenuation in RAW 264.7 murine macrophages. RAW 264.7 murine macrophages were used to assess the intracellular survival of B. abortus $2308, B$. melitensis $027,2308 \Delta$ ery and $027 \Delta$ ery. RAW 264.7 cells were infected as previously described (14). Briefly, $5 \times 10^{5}$ cells/well were cultured in 24 -well plates for $16 \mathrm{~h}$ at $37^{\circ} \mathrm{C}$ and infected with Brucella at a multiplicity of infection (MOI) of 100. Culture plates were centrifuged for $5 \mathrm{~min}$ at $350 \mathrm{xg}$ at room temperature and placed in an incubator at $37^{\circ} \mathrm{C}$ with $5 \% \mathrm{CO}_{2}$ atmosphere. At 45 min post-infection, the cells were washed twice with media and then incubated with Dulbecco's modified Eagle's medium (DMEM; Gibco; Thermo Fisher Scientific, Inc., Rockville, MD, USA) containing $50 \mu \mathrm{g} / \mathrm{ml}$ gentamicin (Invitrogen; Thermo Fisher Scientific, Inc.) for $1 \mathrm{~h}$ to kill extracellular bacteria. The media was then replaced with DMEM containing $25 \mu \mathrm{g} / \mathrm{ml}$ gentamicin (incubation point $0 \mathrm{~min}$ ). At 4, 12, 24 and $48 \mathrm{~h}$ post-infection, the number of colony-forming units (CFU) was obtained by plating serial dilutions of the lysates on TSA plates. All assays were performed in triplicate and repeated at least three times.

HPT-8 cells invasion assay. HPT-8 cells were infected by B. abortus 2308 and B. melitensis 027 in media with or without erythritol $(20 \mathrm{mM})$. HPT-8 cells were grown at $37^{\circ} \mathrm{C}$ in a $5 \% \mathrm{CO}_{2}$ atmosphere in DMEM containing $20 \%$ fetal bovine serum (Gibco; Thermo Fisher Scientific, Inc.). Cells were seeded $\left(1 \times 10^{6}\right)$ in 12 -well culture dishes $24 \mathrm{~h}$ prior to each infection assay. HPT- 8 cells were infected at a MOI of 100 bacteria per cell as previously described $(14,15)$. Culture plates were centrifuged for $5 \mathrm{~min}$ at $350 \mathrm{xg}$ at room temperature. Post-infection, cells were grown in the presence of erythritol at a concentration of $1 \%$ as a nutritional supplement or at $20 \mathrm{mM}$ for induction of the ery operon and placed in an incubator at $37^{\circ} \mathrm{C}$ with $5 \% \mathrm{CO}_{2}$ atmosphere. Cells were washed three times with phosphate-buffered saline (PBS) and monolayers of cells were further incubated with culture media supplemented with $50 \mu \mathrm{g} / \mathrm{ml}$ gentamicin for $1 \mathrm{~h}$ to kill extracellular bacteria. The cells were washed with DMEM containing $10 \%$ fetal bovine serum to remove gentamicin, then the cells were lysed with TRIzol reagent (Invitrogen; Thermo Fisher Scientific, Inc.).

RNA isolation and reverse transcription. Total RNA (1 $\mu \mathrm{g})$ from HPT-8 cells at 0 min (bacterial culture), $20 \mathrm{~min}, 1 \mathrm{~h}$, $2 \mathrm{~h}, 3 \mathrm{~h}, 4 \mathrm{~h}$ and $12 \mathrm{~h}$ post-infection was isolated (Qiagen RNeasy Mini-kits; Qiagen, Hilden, Germany) and cDNA was generated using random hexamer primers and MMLV-RT according to the manufacturer's recommendations (Gibco; Thermo Fisher Scientific, Inc.). Genomic DNA was removed using a DNase RT kit (Invitrogen; Thermo Fisher Scientific, Inc.), according to the manufacturer's instructions. The $10 \mu \mathrm{l}$ reaction mixture system containing $1 \mu \mathrm{g}$ RNA, $1 \mathrm{U}$ DNase, $1 \mu \mathrm{l}$ DNase buffer and ddH2O was added to $10 \mu \mathrm{l}$. The mixture system was mixed and allowed to rest for $10 \mathrm{~min}$ at room temperature. A total of $1 \mu 125 \mathrm{mM}$ EDTA was added and incubated for $10 \mathrm{~min}$ at $65^{\circ} \mathrm{C}$. The DNA polymerase was obtained from Invitrogen (Thermo Fisher Scientific, Inc.). cDNA was stored at $-80^{\circ} \mathrm{C}$ and used as a template for reverse transcription-quantitative polymerase chain reaction (RT-qPCR).

Oligonucleotide primers. TaqMan primers for $16 \mathrm{~S}$ rRNA (housekeeping gene), eryA, eryB, eryC and eryD genes were designed using Primer Express 5.0 software (Applied Biosystems, Palo Alto, CA, USA) according to sequences in GenBank (http://www.ncbi.nlm.nih.gov/genbank/) (Table II).

Construction of recombinant plasmids. Ery operon (eryA, $\operatorname{ery} B, \operatorname{ery} C$ and $\operatorname{ery} D$ ) and $16 \mathrm{~S}$ rRNA open reading frames were amplified by PCR with specific primers (see Table II; Premier Biosoft, Palo Alto, CA, USA) from the B. abortus 2308 genome. The amplified DNA fragments and pMD18-T simple vectors were ligated overnight at $16^{\circ} \mathrm{C}$ using T4 DNA ligase (Takara Bio, Inc.). The ligation reaction was transformed into E. coli JM109, and insert-containing plasmids were identified by restriction analysis or PCR. Positive recombinant plasmids were sequenced to confirm the correct construction. 
Table I. Bacterial strains and plasmids used in this study.

\begin{tabular}{|c|c|c|}
\hline Name & Description & Source \\
\hline \multicolumn{3}{|l|}{ Bacteria strain } \\
\hline Brucella abortus 2308 & Wild-type, virulent strain & China CDC \\
\hline Brucella melitensis 027 & Biotype 3 , virulent strain (China), identified by China CDC & Present study \\
\hline $2308 \Delta e r y$ & $\Delta e r y$ promoter mutant of strain 2308 & Present study \\
\hline $027 \Delta e r y$ & Sery promoter mutant of strain 027 & Present study \\
\hline Escherichia coli JM109 & $\begin{array}{l}\text { end } \mathrm{A} 1, \operatorname{rec} \mathrm{A} 1, \text { gyr } \mathrm{A} 96, \text { thi, hsd } \mathrm{R} 17\left(\mathrm{r}_{\mathrm{k}^{-}}, \mathrm{m}_{\mathrm{k}}+\right) \text {, relA } 1 \text {, } \\
\text { sup } \mathrm{E} 44, \Delta(\text { lac-pro } \mathrm{AB}),\left[\mathrm{F}^{\prime}, \text { tra } \mathrm{D} 36, \text { pro } \mathrm{AB}, \text { laq } \mathrm{IqZ} \Delta \mathrm{M} 15\right]\end{array}$ & Promega \\
\hline \multicolumn{3}{|l|}{ Plasmid } \\
\hline pMD18-T simple vector & Broad-host range vector; Amp ${ }^{r}$ & Takara \\
\hline pMD18-eryA & $\begin{array}{l}\text { pMD18-T containing } 87 \mathrm{bp} \text { fragment amplified with } \\
\text { eryA-RT-S and } \text { eryA-RT-A including a fraction of } \text { eryA }\end{array}$ & Present study \\
\hline pMD18-eryB & $\begin{array}{l}\text { pMD18-T containing } 104 \text { bp fragment amplified with } \\
\text { eryB-RT-S and } \text { eryB-RT-A including a fraction of eryB }\end{array}$ & Present study \\
\hline pMD18-eryC & $\begin{array}{l}\text { pMD18-T containing } 118 \text { bp fragment amplified with } \\
\text { eryC-RT-S and } \text { eryC-RT-A including a fraction of eryC }\end{array}$ & Present study \\
\hline pMD18-eryD & $\begin{array}{l}\text { pMD18-T containing } 120 \text { bp fragment amplified with } \\
\text { eryD-RT-S and eryD-RT-A including a fraction of eryD }\end{array}$ & Present study \\
\hline pMD18-16S rRNA & $\begin{array}{l}\text { pMD18-T containing } 88 \mathrm{bp} \text { fragment amplified with } \\
\text { 16s-RNA-S and 16s-RNA-A including a fraction of 16S rRNA }\end{array}$ & Present study \\
\hline
\end{tabular}

Transcriptional analysis of ery operon genes by RT-qPCR. The concentration and purity of recombinant plasmids (dilution, x100) were measured using a Nanodrop 2000 Spectrophotometer (Thermo Fisher Scientific, Inc.) and used to compute target gene copy numbers. A three-step, 45-cycle RT-qPCR method was conducted using a LightCycler ${ }^{\circledR} 480$ System (Roche Diagnostics, Basel, Switzerland). A linear standard curve was created with the LightCycler ${ }^{\circledR} 480$ System Software and serial dilutions of recombinant plasmids containing the genes encoding $16 \mathrm{~S}$ rRNA, ery $A$, ery $B$, ery $C$ and $e r y D$. RT-qPCR was conducted with the following reaction conditions: $5 \mathrm{~min}$ at $95^{\circ} \mathrm{C}$, followed by 45 cycles at $58^{\circ} \mathrm{C}$ for $30 \mathrm{sec}$ and $72^{\circ} \mathrm{C}$ for $30 \mathrm{sec}$. A negative control (no cDNA) and RT control (no reverse transcription) were used in the experiments. All assays were performed in triplicate and repeated at least three times. The expression levels of the target genes were calculated by comparison with cycle threshold $(\mathrm{Ct})$ and determined at $0 \mathrm{~min}, 20 \mathrm{~min}, 1 \mathrm{~h}, 2 \mathrm{~h}, 3 \mathrm{~h}$, $4 \mathrm{~h}$ and $12 \mathrm{~h}$ post-infection. 16S rRNA expression was used as a reference value to compare the relative expression levels at the various time points. Target genes were amplified in triplicate using the LightCycler ${ }^{\circledR} 480$ System, and the data were presented as the mean of each triplicate with standard deviations (SDs). All assays were repeated a minimum of three times.

Statistical analysis. The data were analyzed using Student's t-test and expressed as the mean value \pm SD. The differences between groups were analyzed by analysis of variance using SPSS 17.0 software (SPSS, Inc., Chicago, IL, USA). P<0.05 was considered to indicate a statistically significant difference.
Table II. Primer sequences used in this study.

\begin{tabular}{lc}
\hline Primer & \multicolumn{1}{c}{ Sequence } \\
\hline 16S rRNA-RT-sense & GCGGCTCACTGGTCCATTAC \\
16S rRNA-RT-anti-sense & CGTTTACGGCGTGGACTACC \\
ery $A$-RT-sense & CGCACACGCCAGTATGATGA \\
ery $A$-RT-anti-sense & CGACCCGTCGATGATTTCAG \\
ery $B$-RT-sense & GAGATTGCCAATGCCGATTA \\
ery $B$-RT-anti-sense & GCACCATAGAGCCGTCCATA \\
ery $C$-RT-sense & GCTTTCGCTCAACACCAATC \\
ery $C$-RT-anti-sense & CATGGGTAAGCTGGAGGTCA \\
ery $D$-RT-sense & CGTGGAAAACGCCGATATGA \\
ery $D$-RT-anti-sense & GTCCGTTCGTCGGTGATGAG
\end{tabular}

\section{Results}

ery operon was successfully deleted in B. abortus 2308 and $B$. melitensis 027 . The ery operon deletion was confirmed by

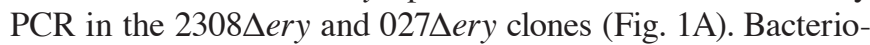
logical analysis and typing of the mutant showed that deletion of the ery gene was stable after passage in culture media (Fig. 1B).

Growth curve of 23084ery and 0274ery. To test whether deletion of the ery operon affected the growth of 2308 or 027 , we measured the bacterial growth in nutrient-replete (TSB 7.0) media. When cultured in normal TSB media, 2308 $\Delta$ ery and $027 \Delta$ ery displayed a similar lag phase and reached the stationary phase at a similar optical density compared with 2308 and 027 (Fig. 2A). 

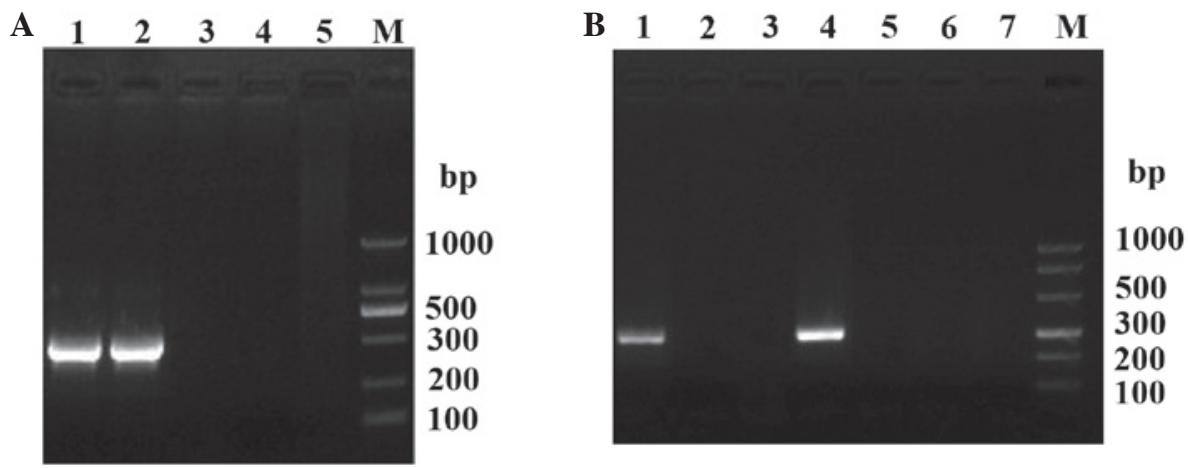

Figure 1. Identification of construction of the $2308 \Delta$ ery and $027 \Delta$ ery. (A) Polymerase chain reaction identification of $2308 \Delta$ ery and $027 \Delta$ ery. Lanes: 1 , the strain

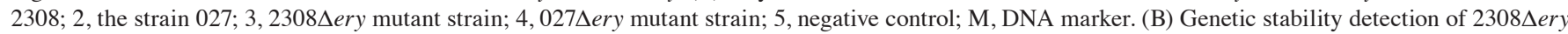

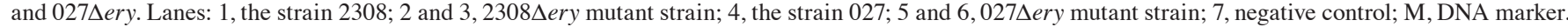
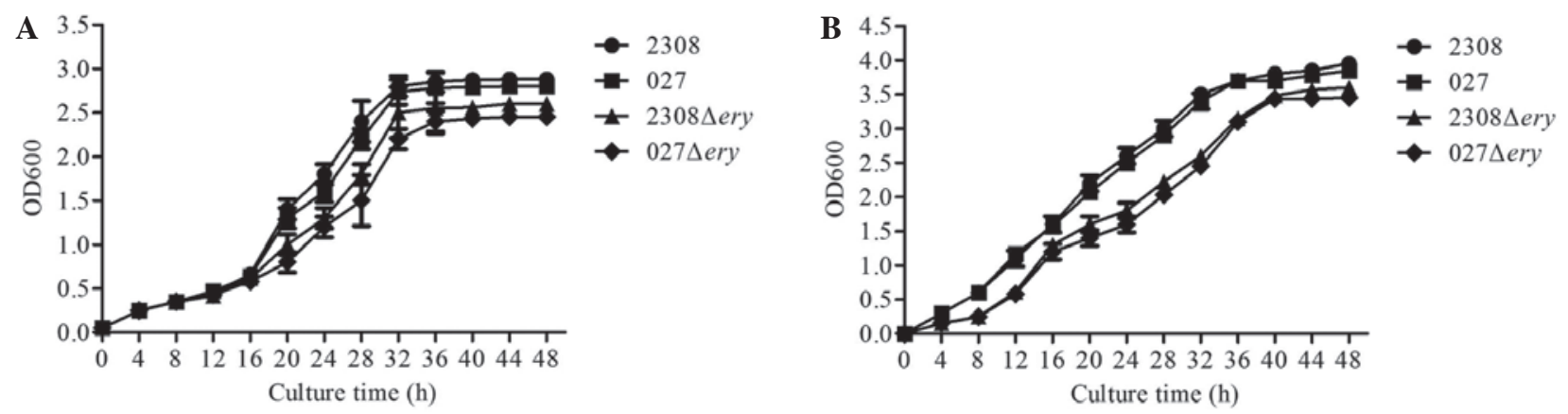

Figure 2. Growth curves of Brucella strains in (A) nutrient-replete (TSB 7.0) media (A) or containing (B) erythritol (20 mM). The OD600 value was measured to determine growth.

Erythritol growth response in 23084ery and 0274ery. To test

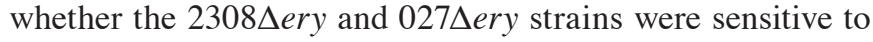
erythritol when grown in broth containing erythritol $(20 \mathrm{mM})$, we measured the bacterial growth. The results showed that the virulent strains 2308 and 027 grew well in broth containing erythritol; however, the $2308 \Delta$ ery and $027 \Delta$ ery mutants grew at a slower rate (Fig. 2B). These results indicated that 2308 $\Delta$ ery and $027 \Delta$ ery do not respond to erythritol, and that the virulent strains 2308 and 027 may utilize erythritol for growth.

23084ery and 0274ery are attenuated and experience reduced survival in macrophages. To assess whether the ery operon influences virulence, RAW 264.7 macrophages were infected with $2308 \Delta$ ery, $027 \Delta$ ery, 2308 and 027 . The surviving bacteria were enumerated, and there was no difference in the number of surviving bacteria $4 \mathrm{~h}$ post-infection (Fig. $3 ; \mathrm{P}>0.05$ ). This indicated that deletion of the ery operon does not affect macrophage invasion. However, at $12 \mathrm{~h}$ post-infection, there was a $1.50-\log$ decrease $(\mathrm{P}<0.05)$ in the number of $2308 \Delta$ ery compared to 2308 , and there was a $1.55-\log$ decrease $(\mathrm{P}<0.05)$ in the number of $027 \Delta$ ery compared to 027 (Fig. 3). At $24 \mathrm{~h}$ post-infection there was a 2.70-log decrease in the number of 2308 $\Delta$ ery compared to 2308 (Fig. 3; $\mathrm{P}<0.01$ ); and there was a $2.70-\log$ decrease in the number of $027 \Delta$ ery compared to 027 (Fig. 3; $\mathrm{P}<0.01$ ). At $48 \mathrm{~h}$ post-infection, there was a $4.10-\log$ decrease in the number of $2308 \Delta$ ery compared to 2308 (Fig. 3; $\mathrm{P}<0.01$ ); and there was a 4.00-log decrease in the number of $027 \Delta$ ery compared to 027 (Fig. 3; P<0.01). Therefore, 2308 $\Delta$ ery and $027 \Delta$ ery mutants had a replication defect in RAW264.7 macrophages.

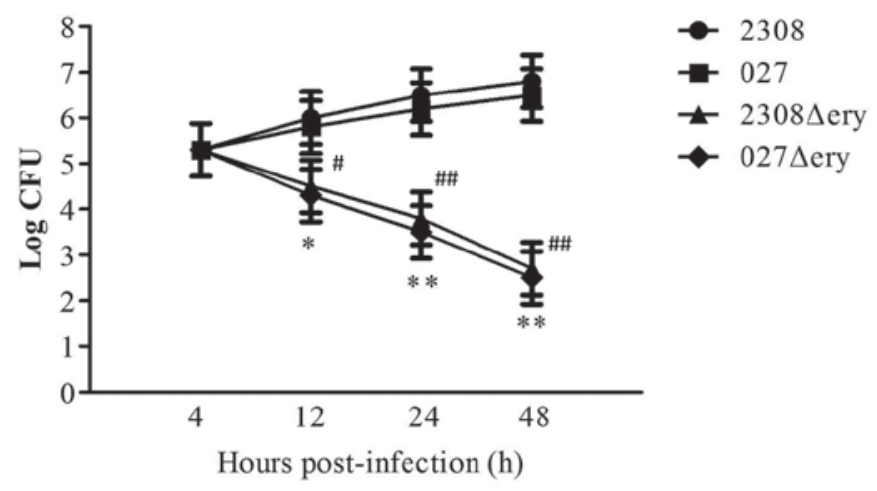

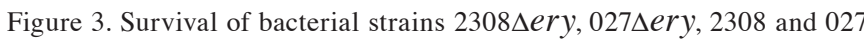
in RAW 264.7 macrophages. Monolayers of macrophages were infected with Brucella at 4, 12, 24 and $48 \mathrm{~h}$ post-infection, the macrophages were lysed and supernatants were diluted for colony-forming factor enumeration. Significant differences in replication are indicated as follows: Significant differences between $2308 \Delta$ ery and 2308 are indicated by ${ }^{*} \mathrm{P}<0.05$ and ${ }^{* *} \mathrm{P}<0.01$. Significant differences between $027 \Delta$ ery and 027 are indicated as follows ${ }^{\#} \mathrm{P}<0.05$ and ${ }^{\# \#} \mathrm{P}<0.01$.

Preparation of standard curves of different genes by RT-qPCR assay. The equations for the linear regression line for the standard curves of different genes generated by RT-qPCR assay and the corresponding $R^{2}$ value are as follows: $16 \mathrm{~S}$ rRNA, $\mathrm{y}=0.238 \mathrm{x}+11.041, R^{2}=0.986 ;$ eryA, $\mathrm{y}=-0.267 \mathrm{x}+12.217$, $R^{2}=0.986 ;$ ery $B, \mathrm{y}=-0.266 \mathrm{x}+11.081, R^{2}=0.983 ;$ ery $C$, $\mathrm{y}=-0.216 \mathrm{x}+10.165, R^{2}=0.977$; and $\operatorname{ery} D, \mathrm{y}=-0.297 \mathrm{x}+11.414$, $R^{2}=0.995$. Based on the slope rates of these regression lines, 

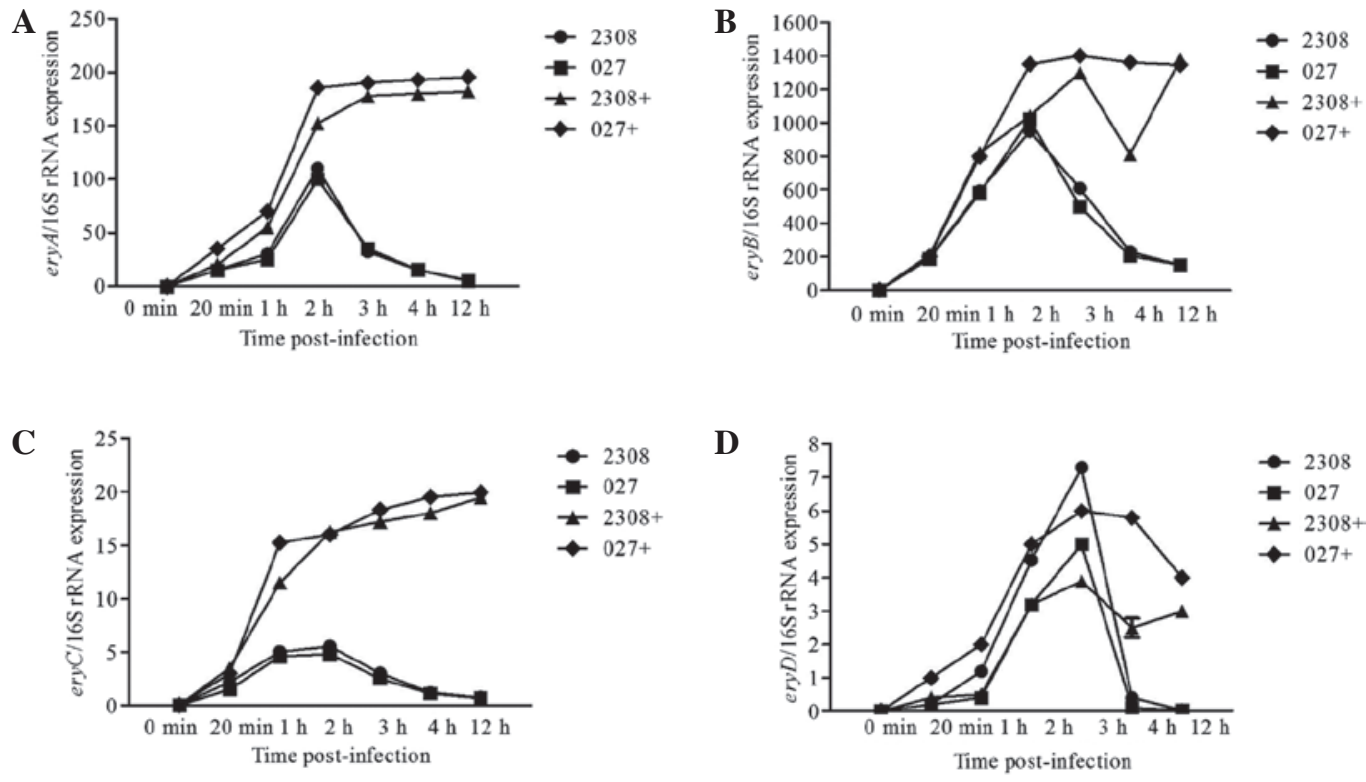

Figure 4. Relative expression level of eryA (A), eryB (B), eryC (C) and eryD (D) of Brucella abortus 2308 and Brucella melitensis 027 in media with or without erythritol $(20 \mathrm{mM})$ at several time points. Growth of B. abortus 2308 and B. melitensis 027 grown in media without erythritol. In addition, expression in B. abortus $2308+$ and $B$. melitensis $027+$ were followed in the presence of erythritol $(20 \mathrm{mM})$. The relative expression of ery $A$, ery $B$ and ery $C$ peaked at $2 \mathrm{~h}$ post-infection in HPT- 8 cells, and that ery $D$ expression peaks at $3 \mathrm{~h}$ post-infection. Data points represent means of triplicate reactions, and error bars indicate standard deviation. The data set is representative of three independent experiments using the same sample.

the levels of amplification efficiency $\left(\mathrm{E}=10^{-\mathrm{a}}-1\right)$ were $72.98 \%$ for $16 \mathrm{~S}$ rRNA, $84.93 \%$ for eryA, $84.50 \%$ for $\operatorname{ery} B, 64.44 \%$ for ery $C, 98.15 \%$ for $e r y D$. Melt curve (unpublished) analysis of amplification products indicated that there was a single peak with a Tm of $86.8^{\circ} \mathrm{C}$ for $16 \mathrm{~S}$ rRNA, $86.2^{\circ} \mathrm{C}$ for $\operatorname{ery} A, 84.6^{\circ} \mathrm{C}$ for ery $B, 90.06^{\circ} \mathrm{C}$ for $e r y C$ and $91.75^{\circ} \mathrm{C}$ for $\operatorname{ery} D$.

Ery operon gene expression following infection: We analyzed gene expression at $0 \mathrm{~min}, 20 \mathrm{~min}, 1 \mathrm{~h}, 2 \mathrm{~h}, 3 \mathrm{~h}, 4 \mathrm{~h}$ and $12 \mathrm{~h}$ post-infection. The relative expression levels of ery $A$, eryB, ery $C$ and $e r y D$ were significantly higher in Brucella grown with medium containing erythritol. Furthermore, the relative expression levels of ery $A$, ery $B$ and ery $C$ were highest $(\mathrm{P}<0.01)$ at $2 \mathrm{~h}$ post-infection (Fig. $4 \mathrm{~A}-\mathrm{C})$, but were highest $(\mathrm{P}<0.01)$ at $3 \mathrm{~h}$ post-infection for eryD $(\mathrm{P}<0.05)$ (Fig. 4D). Gene expression levels were calculated based on the comparison to the expression of $16 \mathrm{~S}$ rRNA. Based on these calculations, ery $B$ was the most highly expressed gene followed by ery $A$, ery $C$ and $\operatorname{ery} D$ (Fig. 5).

\section{Discussion}

The majority of Brucella spp. utilize erythritol to promote growth (except B. abortus S19). Metabolism and usage of erythritol are regulated by the 7.7-kb eryoperon, which consists of four genes eryA, eryB, eryC and eryD (EryA, 519 AA; EryB, 502 AA; EryC, 309 AA and EryD, 316 AA) (16-18). The functions of these four proteases are similar to xylulose kinase (E. coli $x y l B)$, glycerol-3-phosphate dehydrogenase (E. coli glpD), hydrogenase (Alcaligenes hydrogenophilus hupL), operon regulators (Rhodobacter sphaeroides smoC and Klebsiella pneumoniae dalR) (10). In addition, the promoter of the ery operon also includes an integration host factor binding site. This study demonstrates that the

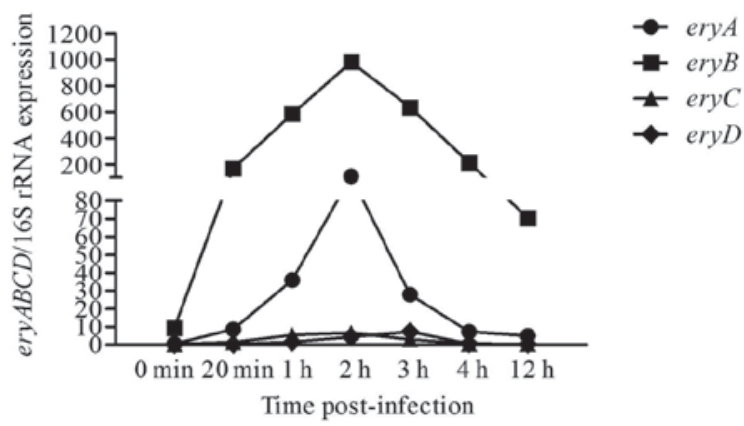

Figure 5. Comparison of the relative expression levels of ery operon, including ery $A, \operatorname{ery} B$, ery $C$ and ery $D$, in Brucella melitensis strain 2308 at different time points. Each value in the figure represents the mean of triplicate experiments \pm standard deviation.

expression of the ery operon in HPT-8 cells is higher than in culture medium, and suggests that the B. melitensis 027 ery operon is induced by erythritol within HPT-8 cells. Furthermore, the expression of the ery $D$ gene may repress the expression of the other genes in the operon. This is the first demonstration of the expression and regulation of the ery operon of $B$. melitensis in human trophoblast cells.

Brucella is detected in non-professional phagocytes 30 min post-infection (19). Therefore, the infection time used in this study was $20 \mathrm{~min}$, at which time Brucella were detectable within host cells. Once entry has been established a brucellosome is formed, a process that lasts 2-3 h. To study the expression of the ery operon during the initial stage of infection, we measured ery operon expression at $20 \mathrm{~min}, 1 \mathrm{~h}, 2 \mathrm{~h}, 3 \mathrm{~h}$ and $4 \mathrm{~h}$ post-infection in HPT- 8 cells. In addition, the expression of the ery operon was measured at $12 \mathrm{~h}$ post-infection and was markedly decreased, which may be due to changes in the intracellular environment induced by Brucella. Notably, HPT-8 
cells easily detached from the culture flask after infection. In general, longer infection times correlated with higher levels of detachment. In this study, we used expression of the $16 \mathrm{~S}$ rRNA gene as a reference to eliminate determine genes expression levels at $20 \mathrm{~min}, 1 \mathrm{~h}, 2 \mathrm{~h}, 3 \mathrm{~h}, 4 \mathrm{~h}$ and $12 \mathrm{~h}$ post-infection.

Numerous genes from pathogen bacteria, such as Brucella and Mycobacterium tuberculosis, are regulated by environment signals in vitro (20). Mariani et al (17) investigated the expression of 14 genes in Mycobacterium tuberculosis H37Rv in both medium and macrophages. Five of these genes were expressed in media and macrophages, four genes were expressed in media, and the remaining five genes were only expressed in macrophages. In this study, we characterized the expression of the ery operon in media and at different timepoints following infection.

All four genes of the ery operon are essential for optimal Brucella virulence. The function of the genes in the ery operon control erythritol catabolism, which has been postulated to increase virulence in the host environment (21). Cells infected with Brucella were grown in liquid media with or without erythritol at a concentration of $20 \mathrm{mM}$. During the early phase of infection without erythritol, the expression levels of $\operatorname{eryA}-C$ are highest at $2 \mathrm{~h}$ post-infection; $\operatorname{ery} D$ is highest at $3 \mathrm{~h}$ post-infection. Therefore, as $\operatorname{ery} D$ expression increased the expression of eryA-C declined (Fig. 4). When erythritol was present in the media, expression was similar to the above-mentioned results. However, the expression levels of eryA-C peaked at $2 \mathrm{~h}$ then remained constant, whereas eryD peaked at $3 \mathrm{~h}$ and then declined (Fig. 5). Two explanations may account for this phenomenon. First, EryD protein expression may inhibit transcription of the ery operon (7). A second explanation may involve acidification of the brucellosome at $3 \mathrm{~h}$ post-infection, as multiplication in the acidified-brucellosome may represent a starvation condition due to decreased ery operon expression induced by erythritol.

Trophoblastic cells contain high levels of erythritols and are targeted for infection by Brucella. It has been previously reported that Brucella preferentially utilizes the carbon source erythritol. This study demonstrates that the expression of the ery operon is significantly lower in media compared with trophoplastic cells.

Therefore, the present results indicate that the expression of the ery operon of $B$. melitensis 027 differs when grown in media or HPT-8 cells, and that this expression is regulated by environmental signals. Specifically, the ery operon is induced by erythritol after entry into HPT-8 cells. However, a number of questions remain to be answered before we can understand the role of the Ery system in Brucella virulence.

\section{Acknowledgements}

The present study was supported by grants from the International Science and Technology Cooperation Project of China (grant nos. 2013BC005 and 2015DFR31110), the Outstanding Youth Project of Shihezi University (grant no. 2012ZRKXJQ02), the National Natural Science Foundation of China (grant nos. 31460650 and 31260596), and the University Key Research Project of Henan Province (grant no. 16A230013).

\section{References}

1. Bercovich Z: The use of skin delayed-type hypersensitivity as an adjunct test to diagnose brucellosis in cattle: A review. Vet Q 22: $123-130,2000$

2. Pappas G, Papadimitriou P, Akritidis N, Christou L and Tsianos EV: The new global map of human brucellosis. Lancet Infect Dis 6: 91-99, 2006.

3. Boschiroli ML, Foulongne V and O'Callaghan D: Brucellosis: A worldwide zoonosis. Curr Opin Microbiol 4: 58-64, 2001.

4. Köhler S, Michaux-Charachon S, Porte F, Ramuz M and Liautard JP: What is the nature of the replicative niche of a stealthy bug named Brucella? Trends Microbiol 11: 215-219, 2003.

5. Roop RM II, Gee JM, Robertson GT, Richardson JM, Ng WL and Winkler ME: Brucella stationary-phase gene expression and virulence. Ann Rev Microbiol 57: 57-76, 2003.

6. Anderson JD and Smith H: The metabolism of erythritol by Brucella abortus. J Gen Microbiol 38: 109-124, 1965.

7. Meyer ME: Metabolic characterization of the genus Brucella VI. Growth stimulation by i-erythritol compared with strain virulence for guinea pigs. J Bacteriol 93: 996-1000, 1967.

8. Keppie J, Williams AE, Witt $\mathrm{K}$ and Smith $\mathrm{H}$ : The role of erythritol in the tissue localization of the Brucellae. Br J Exp Pathol 46: 104-108, 1965.

9. Delrue RM, Lestrate P, Tibor A, Letesson JJ and De Bolle X: Brucella pathogenesis, genes identified from random large-scale screens. FEMS Microbiol Lett 231: 1-12, 2004.

10. Sangari FJ, Agüero J and García-Lobo JM: The genes for erythritol catabolism are organized as an inducible operon in Brucella abortus. Microbiology 146: 487-495, 2000.

11. Burkhardt S, Jiménez de Bagüés MP, Liautard JP and Köhler S: Analysis of the behavior of eryC mutants of Brucella suis attenuated in macrophages. Infect Immun 73: 6782-6790, 2005.

12. Eoh H, Jeon BY, Kim Z, Kim SC and Cho SN: Expression and validation of D-erythrulose 1-phosphate dehydrogenase from Brucella abortus: A diagnostic reagent for bovine brucellosis. J Vet Diagn Invest 22: 524-530, 2010.

13. Zhang J, Yin S, Guo F, Meng R, Chen C, Zhang H, Li Z, Fu Q, Shi H, Hu S, et al: A potent Brucella abortus $2308 \Delta$ ery live vaccine allows for the differentiation between natural and vaccinated infection. J Microbiol 52: 681-688, 2014.

14. Hernández-Castro R, Verdugo-Rodríguez A, Puente JL and Suárez-Güemes F: The BMEI0216 gene of Brucella melitensis is required for internalization in HeLa cells. Microb Pathog 44: 28-33, 2008.

15. Pizarro-Cerdá J, Méresse S, Parton RG, van der Goot G, Sola-Landa A, Lopez-Goñi I, Moreno E and Gorvel JP: Brucella abortus transits through the autophagic pathway and replicates in the endoplasmic reticulum of nonprofessional phagocytes. Infect Immun 66: 5711-5724, 1998.

16. Lillo AM, Tetzlaff CN, Sangari FJ and Cane DE: Functional expression and characterization of EryA, the erythritol kinase of Brucella abortus and enzymatic synthesis of 1-Erythritol-4-phosphate. Bioorg Med Chem Lett 13: 737-739, 2003.

17. Mariani F, Cappelli G, Riccardi G and Colizzi V: Mycobacterium tuberculosis $\mathrm{H} 37 \mathrm{Rv}$ comparative gene-expression analysis in synthetic medium and human macrophage. Gene 253: 281-291, 2000.

18. Smith H, Williams AE, Pearce JH, Keppie J, Harris-smith PW, Fitz-George RB and Witt K: Foetal erythritol: A cause of the localization of Brucella abortus in bovine contagious abortion. Nature 193: 47-49, 1962.

19. Watanabe K, Tachibana M, Tanaka S, Furuoka H, Horiuchi M, Suzuki H and Watarai M: Heat shock cognate protein 70 contributes to Brucella invasion into trophoblast giant cells that cause infectious abortion. BMC Microbiol 8: 212, 2008.

20. Wang Y, Chen Z, Qiao F, Zhong Z, Xu J, Wang Z, Du X, Qu Q, Yuan J, Jia L, et al: The type IV secretion system affects the expression of Omp25/Omp31 and the outer membrane properties of Brucella melitensis. FEMS Microbiol Lett 303: 92-100, 2010.

21. Dizon-Townson DS, Lu J, Morgan TK and Ward KJ: Genetic expression by fetal chorionic villi during the first trimester of human gestation. Am J Obstet Gynecol 183: 706-711, 2000. 